\title{
KiBlat Analysis for Stock Selection with Growth Earning Lynch Model
}

\author{
Niken Savitri Primasari 1, ${ }^{1,}$, Mohammad Ghofirin ${ }^{2}$ \\ ${ }^{1,2}$ Department of Accounting, Faculty of Economic Business and Technology Digital, Universitas Nahdlatul Ulama Surabaya, \\ Indonesia \\ ${ }^{*}$ Corresponding author. Email: niken@unusa.ac.id
}

\begin{abstract}
This study was conducted to find an easier screening method, by combining Piotroski and greenblatt then be called KiBlat analysis that has been screened early with modifications to the Growth Earning Lynch Model. The modified screening with KiBlat analysis will be proven in the research period 2015 - 2018. Restrictions in that period are intended to avoid stock market anomaly such as the presidential election in 2014 and 2019 then the anomaly covid 19 in 2020 . We used quantitative approach, the initial stage of research conducted data validation by classifying stocks based on Lynch model method and taking data on go-public companies during the research period. The next analysis of this validated stock selection will be reanalyzed by making Piotroski modifications with Greenblatt magic formula. The result will be compared to the historical return of the market for the selection of these stocks. Data analysis was performing by multiple linear regression analysis method. The results of this study showed that the stock selection with validation Earning Lynch Model and analysis it with Piotroski then greeenblatt magic formula has significant impact toward the stock return on companies listed.
\end{abstract}

Keywords: Greenblatt, Investment, Lynch, Piotroski, Stocks

\section{INTRODUCTION}

Many various methods of stock screening using fundamental analysis of financial ratios have sprung up. Some of them are the method of stock evaluation screening methods Graham, Lynch (1989), Piotroski and Greenblatt. From literature studies which is the state of the art of this method research, seen from the collection of research sourced from google scholar from 2013 - early 2020, it was found that fundamental financial research in Indonesia that suggests about the method is still very rare. Piotroski method research filtered there are only 4 studies, then greenblatt and Lynch method only seen 1 study with research object for stocks included in LQ-45 and Kompas 100 index.

Furthermore, by looking at the problems that often occur, especially in novice investors who tend to find it difficult to perform fundamental analysis stages, then based on the results of previous research that shows the results of screening methods with a predicted return level in accordance with the return contained in the market, research that modifies this screening method is conducted.

The initial stage of the stock screening method was done by means of Lynch (1989)'s fundamentalist analysis that focused on price earnings growth. The shares will then proceed with the second phase, which uses Piotroski analysis and the final stage of decision-making with the Greenblatt method. Novelty research is shown from combining the analysis of Piotroski and Greenblatt, which will then be referred to as the KiBlat analysis method for investment assessment.
Reviewing the literature study, the phenomenon of increasing the number of SIDs and investor needs for stock valuation, this study was conducted

\section{OBJECTIVES OF THE STUDY}

The objective of this study was to discover the most suitable screening and assessment method for stock analysis. The first analysis results were based on the screening using the Graham, Lynch method. Subsequently, these results were further analysed with Piotroski and Greenblatt calculation methods. The results of the two methods were then compared to the actual returns of the stocks. KiBlat analysis method analysis method were proven accurate and reliable in predicting the results of share price returns during the period of $2015-2018$

\section{LITERATURE REVIEW \\ 3.1. Signalling Theory}

Uncertainty during IPOs is typically associated with the underwriter's experience and reputation in addition to market situations and organization's longevity (Karlis, Peter, 2000). Although fact discrepancies between issuing organizations and underwriters could be refined using the important agent idea, signalling theories may assist to lessen the impact of discrepancies among underwriters and traders.

Signal Theory is a concept that discusses how corporations provide significant facts, negative facts or alerts for shareholders (Himawan, 2016). Signal Theory explains the reason behind the necessity to offer finance-related 
announcements or facts to external parties. The motive to provide information is due to potential fact discrepancies between organizations and external parties Organizations have more accurate and better understanding of their information and operations compared to outsiders (traders, creditors and potential investors).

Signal theory explains that a company with a good financial performance benefits from the publication of financial statements and provides financial signals to investors in the capital market (Brigham, Houston, 2001).

\subsection{Stock Analysis}

There are several stock analysis techniques (Cooper, et.al., 2012) that can be performed by investors, namely: (1) Fundamental Analysis which is a way of determining the value of shares based on their intrinsic value. Intrinsic value is a very basic value such as the state of assets, products, marketing, revenue growth, dividends, management performance, and others related to the company's prospects and (2) Technical Analysis, which focuses on the price of the security. The results of the analysis are short-term by nature. Investors will never be able to predict if a company's future performance will be similar to its past performance. Another drawback of these two methods is subjectivity due to its heavy reliance on assumptions. This explains the reason why analysis results of one person are different from others'.

\subsection{Lynch Analysis}

In general, Peter Lynch (Lynch, 1989) divided the company into several categories; (The first is fast growers, which include stocks that have a fairly high long-term earning growth (> 20\%). The second is stalwarts, which include stocks that have long-term growth between $10 \%-20 \%$ per an an ounce. The third is slow growers, which include stocks that have eps growth of less than $10 \%$. The fourth is cyclicals, which include companies whose performance depends heavily on economic conditions, for example: car manufacturers, metal producers, and plantations. The fifth is turnarounds, which include companies encountering troubles but there are signs of improvement. If detected early, the potential profit of this type of company is considerable. The sixth is asset plays, which include companies with higher asset values than those recorded in their books. Determining this type of company is relatively simple as one simply needs to figure out exactly the true value of the company's assets. After classifying them into one of these categories, tests were conducted tests to all stocks in those categories.

\subsection{Piotroski Analysis}

Joseph Piotroski formulated a fundamental analysis strategy in conducting investment assessments on companies with a high book-to-market ratio known as the Piotroski FScore strategy with concentrated on three financial conditions including profitability, liabilities, and operational efficiency.

Piotroski developed a fundamental score (F-Score) based on accounting signals that differentiated between companieswith good and bad fundamental scores among all of those with high BM ratios. Piotroski (2000) established that official financial information was useful for the appropriate selection of these companies because (1) the companies tend to be ignored by analysts, (2) the information that companies voluntarily report to the market lacks credibility given their poor recent performance, and (3) the companies tend to be financially distressed (Piotroski , 2000).

Fundamental analysis based on F-Score consists of 9 indicators of measurement of the company's financial performance (Gimeno, et.al.,2020), including return on assets (ROA), change in return on assets $(\triangle \mathrm{ROA})$, cash flow from operations (CFO), accrual, change in leverage ( $\Delta$ leverage), change in liquidity ( $\Delta$ liquidity), change in equity ( $\Delta$ equity), change in gross margin ratio ( $\Delta$ margin) and change in assets turnover ( $\Delta$ turnover). The F-Score score assessment is based on the value of each performance measurement indicator owned by the company. Companies that qualify for good financial performance based on the F-Score will get a score of 1 and companies that do not qualify for a good financial performance assessment get a score of 0 . The total score of the financial performance assessment based on the F-Score range between 0 to 9 (Piotroski , 2000).

\subsection{Greenblatt Analysis}

Greenblatt analysis focuses on finding good-value stocks using a magic formula combined with high earnings yield. The magic formula is used to determine the purchase of shares of companies with good criteria and low share price by using return on capital and high earning yield (Greenblatt, 2010).

Based on the principles of value investing (Rani, 2019), Greenblatt analysis uses two valuation metrics in building a portfolio, namely return on capital (ROC) and earning yield (EY).

Return on capital (ROC) is used to determine how much revenue a company generates using its assets. The higher the ROC result, the better the performance of a company. Return on capital (ROC) is measured by calculating the ratio of operating income before interest and tax or earnings before interest and taxes (EBIT). Earning yield is measured by calculating the ratio of operating income before tax (EBIT) to enterprise value (EV). The higher the yield, the lower the price of a company's shares. This refers to the second principle of investment, buying shares at a low price (Sareewiwatthana, P., 2011).

\subsection{Capital Gain Analysis}

A share price is the price or value of money that one is willing to spend to acquire a share. Under realistic assumptions, capital gain lock-in is indicated to depress the pre-tax returns of securities with accrued capital gains (Klein, 2001). Thus, it can be concluded that a share price is the price formed from the agreement of the seller and the buyer of the shares or the price formed from the market value of the company by both parties. (Indiarti, Widiatmoko, 2021). Basically, a share price is influenced by demand and supply. However, conducting a good stock price assessment requires operational data of the company such as audited financial statements, future company performance and economic conditions. Generally, there are two approaches to assessing stocks (Joga, 2016). 
Selling and buying shares will bring capital gain or capital loss. Where capital gain is an advantage of the difference in the selling price with the purchase price of shares. While capital loss is a loss from the difference in the selling price of shares and the purchase price of shares (Bodie, et.al., 2014). The profits earned will have an impact on the increase in the sale of shares. Therefore, there are two benefits that will be obtained by shareholders, namely dividends and capital gains (Ardinan, 2014).

\section{METHODOLOGY}

\subsection{Research Data}

The researcher will test the stocks selected from Indonesia Stock Exchange. Based to Lynch. Analysis, where the level of growth is for the stocks that have been listed on the exchange for 5 years, therefore the initial data screening had to be in IDX for more than five years from first period 2015, there would be the list start from all data in year 2010. All of the secondary data used in this research are obtained from website, www.idx.co.id. The codes and name of all stocks in the IDX data website required in screening rules based on this research novelty.

\subsection{Screening Rules}

Firstly, the list was sorted based on growth rate according to Peter Lynch (1989), namely (a) fast growers for stocks that have a fairly high long-term earnings growth (> 20\%), (b) stalwarts, for stocks that have long-term growth between $10 \%$ $-20 \%$, and (c) slow growers, for stocks that have earnings growth of less than $10 \%$.

Secondly, the list obtained based on the above Lynch classification was examined using Piotroski analysis and stocks with the F-Score score range of $8-9$ were selected. The results of the assessment in each year of the research period were summed and averaged to represent Piotroski score.

Thirdly, a screening based on Joel's Greenblatt analysis, which examines return on capital (ROC) and earning yield (EY) was carried out. Changes in the increase in ROC and EY in each year were assigned a value of 1 , whereas if the value of ROC or EY decreased or obtained a minus value, it was assigned a value of 0 . The results of the assessment in each year of the research period were summed and averaged to represent the magic formula value of Greenblatt.

\subsection{Analysis Method}

Quantitative research method was utilized in this study to obtain clarity, explain phenomena, explain relationships, test causal relationships between variables, evaluate and discover differences or comparisons between groups, and differences in condition of groups.

A regression analysis tool, namely logistic regression, was used because the dependent variable was dummy (capital gain create or vice versa not gain or loss). Logistic regression is almost similar to discriminant analysis, which is typically used to test whether the probability of occurrence of the dependent variable can be predicted by the independent variable (Sugiyono, 2014).
The overall assessment of the model uses a value of $-2 \log$ likelihood to observe a better model to discover the best model in predicting the formation of capital gains. Cox and Snell's R Square are measures that attempt to imitate the size of R2 in multiple regression. The coefficient of determination (R2) in multiple regression essentially measures how far the model's ability to explain variations in the dependent variable is. The value of the coefficient of determination is between zero and one. A small value of R2 indicates that the ability of the independent variable in explaining the variation of the dependent variable is very limited. A value close to one indicates that the independent variable provides almost all.

The decision to reject or accept the hypothesis is made using a significance level of 5\% Hosmer and Lemeshow's goodness of fit test tests the null hypothesis $(\mathrm{H} 0)$ that the empirical data fits or fits the model (there is no difference between the model and the data so that the model can be deemed suitable.

\subsection{Equation Method}

\subsubsection{Piotroski}

Table 1. Piotroski Criteria and Valuation

\begin{tabular}{|c|l|c|c|}
\hline No & \multicolumn{1}{|c|}{ Criteria } & $\begin{array}{c}\text { Y/N } \\
\text { Answer }\end{array}$ & Score \\
\hline 1 & Positive Net Income & Y & 1 \\
\hline 2 & Positive Operating Cash Flow & Y & 1 \\
\hline 3 & Positif Change in ROA & Y & 1 \\
\hline 4 & OCF > NI & Y & 1 \\
\hline 5 & LTD < Assets & Y & 1 \\
\hline 6 & Positive Change in CR & Y & 1 \\
\hline 7 & Shares Outstanding Stable & Y & 1 \\
\hline 8 & Positive Change Gross Margin & Y & 1 \\
\hline 9 & Positive Change TATO & Y & 1 \\
\hline \multicolumn{2}{|c|}{ Total High Score Piotroski F-Score } & 9 \\
\hline
\end{tabular}

\subsubsection{Greenblatt}

Table 2. Greenblatt Criteria and Valuation

\begin{tabular}{|c|l|c|c|}
\hline No & \multicolumn{1}{|c|}{ Criteria } & $\begin{array}{c}\text { Y/N } \\
\text { Answer }\end{array}$ & Score \\
\hline 1 & Positive Change EY & Y & 1 \\
\hline 2 & Positive Change ROC & Y & 1 \\
\hline \multicolumn{2}{|c|}{ Total High Score Magic Formula Greenblatt Score } & 2 \\
\hline
\end{tabular}

\subsection{3. (KiBlat) Piotroski \& Greenblatt Modification}

Table 3. KiBlat Criteria and Valuation

\begin{tabular}{|c|c|c|c|}
\hline No & Criteria & $\begin{array}{c}\text { Y/N } \\
\text { Answer }\end{array}$ & Score \\
\hline 1 & Positive Net Income & $\mathrm{Y}$ & 1 \\
\hline 2 & Positive Operating Cash Flow & $\mathrm{Y}$ & 1 \\
\hline 3 & Positif Change in ROA & $\mathrm{Y}$ & 1 \\
\hline 4 & $\mathrm{OCF}>\mathrm{NI}$ & $\mathrm{Y}$ & 1 \\
\hline 5 & LTD $<$ Assets & $\mathrm{Y}$ & 1 \\
\hline 6 & Positive Change in CR & $\mathrm{Y}$ & 1 \\
\hline 7 & Shares Outstanding Stable & $\mathrm{Y}$ & 1 \\
\hline 8 & Positive Change Gross Margin & $\mathrm{Y}$ & 1 \\
\hline 9 & Positive Change TATO & $\mathrm{Y}$ & 1 \\
\hline 10 & Positive Change EY & $\mathrm{Y}$ & 1 \\
\hline 11 & Positive Change ROC & $\mathrm{Y}$ & 1 \\
\hline \multicolumn{3}{|c|}{$\begin{array}{r}\text { Total High Score Piotroski Greenblatt modification } \\
\text { (KiBlat) }\end{array}$} & 11 \\
\hline
\end{tabular}




\section{RESULTS AND DISCUSSIONS}

After screening 732 shares listed on IDX, it was observed that during the research period of 2015 - 2018, there were 90 samples established from the screening results.

Table 4. Summary of descriptive analysis

\begin{tabular}{lrrrr}
\hline & $\begin{array}{r}\text { Piotroski } \\
\text { Score }\end{array}$ & $\begin{array}{r}\text { Greeblatt } \\
\text { Score }\end{array}$ & KiBlat & $\begin{array}{r}\text { Gain } \\
\text { Growth }\end{array}$ \\
\hline Mean & 0.9753 & 0.1391 & 0.2605 & 0.7000 \\
\hline $\begin{array}{l}\text { Standard } \\
\text { Deviation }\end{array}$ & 0.0532 & 0.1078 & 0.7537 & 0.4608 \\
\hline $\begin{array}{l}\text { Sample } \\
\text { Variance }\end{array}$ & 0.0029 & 0.0117 & 0.5611 & 0,2120 \\
\hline $\begin{array}{l}\text { Standard } \\
\text { Error }\end{array}$ & 0.2541 & 0.2541 & 0.2541 & 0.2541 \\
\hline
\end{tabular}

Descriptively, the largest standard deviation and variance values belong to variable results of Piotroski and Greenblatt modification gain calculations referred to as Gain results KiBlat Analysis. Furthermore, to observe the correlations between variables matrix, an analysis was conducted and it was detected that, individually, Piotroski value matrix provided a value that was contrary to the value of Y (growth gain in 5 years period research)

Table 5. Correlation matrix

\begin{tabular}{lcccc}
\hline Variable & Constant & $\begin{array}{r}\text { Piotroski } \\
\text { Score }\end{array}$ & $\begin{array}{r}\text { Green } \\
\text { blatt } \\
\text { Score }\end{array}$ & KiBlat \\
\hline Constant & 1.000 & & & \\
\hline $\begin{array}{l}\text { Piotroski } \\
\text { Score }\end{array}$ & -1.000 & 1.000 & & \\
\hline $\begin{array}{l}\text { Greenblatt } \\
\text { Score }\end{array}$ & 0.002 & -0.007 & 1.000 & \\
\hline KiBlat & 0.424 & -0.425 & 0.178 & 1.000 \\
\hline
\end{tabular}

Greenblatt score provided a much better value in predicting gain, even though it only had a correlation value of 0.002 or approximately $0.2 \%$. On the other hand, if the screening was carried out by modifying the Piotroski method with Greenblatt, the final result provided a relationship result worth 0.424 or $42.4 \%$ in predicting the growth value of the stock gain during the research period. With the provisional correlation matrix results, further analysis is needed in binary logit regression to determine whether screening modifications beginning with the Piotroski model and Greenblatt could predict the occurrence of gains in the market that have been kept away from macro-economic anomaly effects.

Table 6. Data Fit and Validation (Iteration Enter Step)

\begin{tabular}{lccc}
\hline Variable & $\begin{array}{r}\text { 2 Log } \\
\text { likelihood }\end{array}$ & $\begin{array}{r}\text { Chi-Square } \\
\text { Critical Value } \\
\text { DF (N-4), 0.05 }\end{array}$ & Coefficients \\
\hline $\begin{array}{l}\text { Piotroski } \\
\text { Score }\end{array}$ & 109.998 & 108.648 & 0.800 \\
\hline $\begin{array}{l}\text { Greenblatt } \\
\text { Score }\end{array}$ & 109.956 & 108.648 & 0.847 \\
\hline $\begin{array}{l}\text { KiBlat } \\
\text { Gain }\end{array}$ & $109.956 *$ & 108.648 & 0.847 \\
\hline *KiBlat Gain estimated detected change at 0.01 & \\
\hline
\end{tabular}

As the initial condition, the data went through assessments and validations by means of iteration, with validation on observed value and fitting equation analysis. Using binary logit regression analysis, it was observed in table 6 that the value of $2 \mathrm{Log}$ likelihood of Piotroski Score had a value 109.998 and others (Greenblatt and KiBlat) had values of 109.956. All three independent variables had a value of more than the critical value of Chi-Square $(89 ; 0.05)$ at 108.648 , therefore the independent variables data were fit.

Table 7. Data Fit and Validation (Oberserved Value)

\begin{tabular}{lrr}
\hline Observed Value Dependent & $\begin{array}{r}\text { Predicted } \\
\text { Value }\end{array}$ & Correct \\
\hline Minus Growth & 27 & 0.0 \\
\hline Positif Growth & 63 & 100.0 \\
\hline Overall Percentage & & 70.0 \\
\hline * Cut Value at 0.05 & &
\end{tabular}

The result of an analysis of the frequency of expectations was based on empirical data of dependent variables, where the number of samples that had a category of variable dependent references or data that had a positive rate of growth was a total of 63 pieces data. On the other hand, the data that had a negative growth rate included 27 pieces of data. The overall percentage result of the data entry indicated that $70 \%$ of the data provided a positive growth value result.

Table 8. Data Fit and Validation (Variables in Equation)

\begin{tabular}{lc}
\hline Equation & Value \\
\hline B & 0.847 \\
\hline Exp $(\mathrm{B})$ & 2.333 \\
\hline S.E & 0.230 \\
\hline Wald & 1.107 \\
\hline $\begin{array}{l}\text { Chi-Square Model } \\
\text { Coefficient }\end{array}$ & 109.955 \\
\hline $\begin{array}{l}\text { Omnibus Significant } \\
\text { Test }\end{array}$ & 0.000 \\
\hline *Cut Value at $0.05(\mathrm{df}=3)$ &
\end{tabular}

The results of analysis before independent variables were inserted into the model and they demonstrated that the Slope Value or Beta Coefficient (B) of constants was 0.847 with an Odds Ratio or $\operatorname{Exp}(\mathrm{B})$ of 2,333 with an Odds Ratio or $\operatorname{Exp}(\mathrm{B})$ of 2,333 , keeping in mind that the value $B$ was identical to the beta coefficient in Ordinary Least Square (OLS) or linear regression, with a standard error value of 0.23 .

The signification value of this omnibus indicated that the addition or merger of independent variables could pose a real influence on the model. Subsequently, the independent variable model against this dependent was declared fit proper and the results of the following statistical analysis could be considered to be the real value and provide a real picture of what is happening in the stock market by eliminating macro anomaly such as the year of the presidential election and covid-19 pandemic.

All of the results of the maximum likelihood test against the hypothesis that KiBlat analysis model with data entry results screening Lynch (1989) method could predict and had 
an influence on the growth of gain value continuously during the research period.

Table 9. Summary Data Result

\begin{tabular}{lc}
\hline Estimation Model & Value \\
\hline Cox \& Snell R Square & 0.705 \\
\hline Nagelkerke R Square & 1.000 \\
\hline Hosmer \& Lemeshow Sig. Test & 0.000 \\
\hline $\begin{array}{l}\text { Independent Variable } \\
\text { Significance to Predicted Y }\end{array}$ & 1.000 \\
\hline D.F & 1.000 \\
\hline *Cut Value at 0.05 &
\end{tabular}

In Table 4, the strength of this KiBlat model can be observed by using Cox \& Snell R Square and Nagelkerke R Square value analysis, as well as the ability of independent variables in describing dependent variables, in this case the continuous growth gain value.

Nagelkerke R Square's value was 1,000 with Cox \&Snell $\mathrm{R}$ Square 0.705, which indicated that the ability of independent variables in describing dependent variables was $100 \%$ and there were no other factors outside the model that could explain the occurrence of value in growth gain.

Analysis of stock investments, especially based on the growth in the value of stock gain, typically begins with a fundamental analysis, which is then further developed with various research that has emerged almost every year. Investors or stock analysts should understand exactly what they are looking for from the results of this analysis.

This study provides an example of the perspective of a number of capital market participants who stand on the side of gain growth that occurs continuously every year. Subsequently, the screening of stock selection is carried out by way of Lynch (1989) Analysis, and is limited to only 3 important categories that focus more on growth, namely (a) fast growers (b) stalwarts and (c) slow growers.

This is in accordance with the criteria of treatment that occurred in the research which stated that exposure growth in gain was more noticeable by most stock exchange players than based on value alone. In addition, the stock screening method which began with Lynch Analysis is supported by the results of a study in 2013, which stated that the stocks selection method based on Lynch's formula and debt-toequity ratio had highest frequency to get highest return in SSE from 2006 to 2011 (Yangsxiu, 2013).

After the first screening, the classification analysis was conducted by looking at the results of the assessment with Piotroski analysis as one of the strategies of treatment of 9 fundamental values of analysis. One of the investment strategies is the ability to review financial statements and. financial reports reflect a company's performance over a certain period. The ability of investors to combine the strategy of value investment and financial statement information is therefore believed to produce greater returns (Shin, Byun, 2012).
One of the fundamental analyses that can be used to evaluate a public company's financial performance is the Piotroski F-Score method, an analysis based on the scoring principle of determining financial variables (Hartono, 2010). Several previous studies have been conducted, including using the F-Score method, and the results indicated that there was a significant premium on stocks with a high F-Score value (Hyde, 2018).

However, when Piotroski analysis was carried out individually, it produced significantly lower results compared to Greenblatt. Regression results indicated that - after controlling well-known risk factors - the three methodologies had generated positive and statistically significant excess returns in the same period. Based on these results, after the Piotroski assessment was conducted, it would be followed by Greenblatt's analysis and the combination of the results of the analysis by validating and applying screening of the results of the growth gain that occurred during the research period. It is important to note that both alpha and beta estimates could vary substantially in different specifications, therefore suggesting that multifactor models may be better suited if the value screening had same relatively movement for the assessment of value investing strategies (Henrique, 2020).

\section{CONCLUSION}

The purpose of this research is to examine if the value investing methods from Peter Lynch (Lynch Analysis), Piotroski and Joel Greenblatt, modified as KiBlat analysis, work in the Indonesia Stock Exchange (IDX).

It was discovered that the growth gains in research period of stocks selected based on Lynch's formula and the modified the model of Piotroski and Greenblatt had detected all the growth gain $100 \%$ predicted for $70,5 \%$ data positive growth.

\section{ACKNOWLEDGMENTS}

Great appreciation to the Institute for Research and Community Service, based on contract UNUSA/AdmLPPM/2021, who had fully supported the entire process of publishing this research.

\section{REFERENCES}

Ardinan, H. (2014). Pengujian Monday Effect pada Bursa Efek Indonesia dan Bursa Efek Singapura (Doctoral dissertation, STIE PERBANAS).

Bodie, Z., Kane, A., Marcus, A. J., \& Mohanty, P. (2014). Investments (SIE). McGraw-Hill Education.

Brigham, E. F., \& Houston, J. F. (2001). Manajemen Keuangan. Buku 1 edisi 8. Jakarta: Erlangga.

Cho, S.-S., Shin, J.-S., \& Byun, J. (2012). The Value of a Two-Dimensional Value Investment Strategy: Evidence from the Korean Stock Market. Emerging Markets Finance and Trade, 48(sup2), 58-81. https://doi.org/10.2753/ree1540-496x48s204.

Gimeno, Ruth, Lidia Lobán, and Luis Vicente. "A neural approach to the value investing tool F-Score." Finance Research Letters 37 (2020): 101367. 
Grenblatt, Greenblatt, J. (2010). The little book that still beats the market (Vol. 29). John Wiley \& Sons.2010).

Hartono, J. (2010). Teori Portofolio dan Analisis Investasi (Edisi Sepuluh). In Yogyakarta: BPFE.

Henrique, Carlos,et.al.,(2020). PIOTROSKI , GRAHAM AND GREENBLATT: AN EMPIRICAL APPROACH TO VALUE INVESTING IN THE BRAZILIAN STOCK MARKET ÁREA.

Himawan, Mey Rianaputri dan Yulius Jogi Christiawan. 2016. Pengaruh Kebijakan Deviden dan Keputusan Pendanaan terhadap Nilai Perusahaan ( Studi pada Sektor Manufaktur yang Terdaftar di BEI Tahun 20102014). Jurnal Akuntansi Bisnis. Volume 4. Nomor 1. Surabaya : Universitas Kristen Petra.

Hyde, C. E. (2018). The Piotroski F - score: evidence from Australia. Accounting \& Finance, 58(2), 423-444..

INDARTI, M. G. K., \& WIDIATMOKO, J. (2021). The Effects of Earnings Management and Audit Quality on Cost of Equity Capital: Empirical Evidence from Indonesia. The Journal of Asian Finance, Economics and Business, 8(4), 769-776..

Joga, J. Analisis Fenomena January Effect Terhadap Return Pasar Di Bursa Efek Indonesia. Riset Manajemen dan Akuntansi STIE Atma Bhakti, 1(2), 221066.

Karlis '00, Peter L. (2000) "IPO Underpricing," The Park Place Economist: Vol. 8.

Klein, P. (2001). The capital gain lock-in effect and longhorizon return reversal. Journal of Financial Economics, 59(1), 33-62.).
Koski, K. (2020). Value in Fundamental Stock Screening: FScore Investment Strategy Performance and Additional Fundamental Analysis in the US Equity Market.

Lynch (1989), P., 1989. One Up On Wall Street: How to Use What You Already Know To Make Money. USA: Simon and Schuster.

Piotroski , J. D. (2000). Value Investing: The Use of Historical Financial Statement Information to Separate Winners from Losers. Journal of Accounting Research. https://doi.org/10.2307/2672906

Qu, W., Cooper, B. J., Wise, V., \& Leung, P. (2012). Voluntary disclosure in a changing regulatory environment: Evidence from Chinese stock market. International Journal of Economics and Finance, 4(4), $30-43$.

Rani, P., 2019. Risk-Reward Agility of the Benjamin Graham and Joel Greenblatt ${ }^{\text {ec }} \mathrm{s}$ Investing Philosophy in the Indian Stock Market. Risk 3085, 492-498.

Sareewiwatthana, P., 2011. Value Investing in Thailand: The Test of Basic Screening Rules, International Review of Business Research Papers.

Sugiyono. (2014). Metode Penelitian Pendidikan pendekatan Kuantitatif, Kualitatif dan R\&D. In METODE PENELITIAN ILMIAH. Kartikasari, D., et al., 2012. "Bristow Group Inc".

Ye, Yangsxiu. (2013). Application of the Stock Selection Criteria of Three Value Investors, Benjamin Graham, Peter Lynch, and Joel Greenblatt: A Case of Shanghai Stock Exchange from 2006 to 2011. International Journal of Scientific and Research Publications, Volume 3, Issue 8, August 2013 (1); ISSN 2250-3153.. 